Отримано: 16 листопада 2021 р.

Прорецензовано: 29 листопада 2021 р.

Прийнято до друку: 04 грудня 2021 р.

e-mail: viktoria.vonrosen@gmail.com

DOI: $10.25264 / 2311-5149-2021-23(51)-67-73$ von Rosen V. Venture capital and its impact on innovative and economic growth of countries. Наукові записки Національного університету "Острозька академія». Серія «Економіка» : науковий журнал. Острог : Вид-во НаУОА, грудень 2021. № 23(51). C. 67-73.

УДК: $339.9+330.8$

JEL-класифікаиія: $G 24$

ORCID-ідентифiкатор: https://orcid.org/0000-0001-6678-0140

Viktoriia von Rosen,

PhD, docent, Institute of Higher Education,

Kyiv National Economic University,

Kyiv, Ukraine

\title{
VENTURE CAPITAL AND ITS IMPACT ON INNOVATIVE AND ECONOMIC GROWTH OF COUNTRIES
}

The article considers the essence of economic and innovative development as well as innovative entrepreneurship. An analysis of venture capital volumes and GDP indicators for selected countries is conducted. The main relationships and factors influencing venture capital processes, such as risk and information asymmetry, are highlighted. The role of venture capital in the innovative and economic development of countries, the practical content of some of the above theoretical provisions are studied. The gap in venture capital issues between countries is also shown. Thus, the gap between the level of development of venture business in the United States and European countries, as well as Japan and Israel, remains significant. The question remains as to why the United States is a leader in the venture capital business. One of the reasons is a developed capital market with the appropriate infrastructure and its main participants. Another reason is less developed (and / or different) social security systems, which forces people to look for other ways to ensure old age through the mechanisms of the private pension system.

Further directions of research on building a model of possible options for innovative development based on the revival of venture capital and the development of innovative entrepreneurship for developing countries are identified. The article notes the stimulating effect of venture capital in the country's innovation and economic growth, as well as the unanimity of conditions and factors influencing the process of venture investment. This also requires further study, as the question of the gap between economic growth, innovation and venture capital for individual countries remains open. Additionally, it is not substanstially analysed, whether the present central bank policy has influenced investors decicions and when this might change.

Keywords: venture capital, innovative growth, economic growth, entrepreneurship.

\author{
Вікторія фон Розен, \\ кандидат економічних наук, дочент, \\ Інститут вищзӧ освіти, \\ ДВНЗ «Київький національний економічний університет \\ імені Вадима Гетьмана»
}

\section{ВЕНЧУРНИЙ КАПІТАЛ І ЙОГО ВПЛИВ НА ІННОВАЦІЙНЕ ТА ЕКОНОМІЧНЕ ЗРОСТАННЯ КРАЇН}

\footnotetext{
У статті розглянуто сутність економічного та інноваційного розвитку, а також інноваційного підприємництвва. Проведено аналіз обсягів венчурного інвестування та показників ВВП за окремо обраними краӥнам. Позначено основні взаємозв'язки та чинники впливу на прочеси венчурного інвестування, такі як ризик та асиметричність інформації. Досліджено роль венчурного капіталу в інноваційному та економічному розвитку країн, продемонстровано практичний зміст окремих наведених теоретичних положень. Також показано відрив в питаннях венчурного інвестування між окремими країнами. Так, суттєвим лишається відрив між рівнем розвитку венчурного бізнесу в США та країнах Свропи, а також Японї та Ізраїлю. Відкритим лишається питання, чому США є лідерами у сфері бізнесу венчурного капіталу. Одна з причин - це розвинений ринок капіталу з відповідною інфраструктурою та основними його учасниками. Інша причина - ие менш розвинена (та/або інша) системами соціального страхування, що змушує людей шукати інших шляхів забезпечення старості через механізми пенсійної системи, де фінансування відбувається приватним иляхом.

Визначено подальші напрями дослідження щуодо побудови моделі можливих варіантів інноваційного розвитку на базі пожвавлення венчурного інвестування та розвитку інноваційного підприємництва для краӥн, щчо розвиваються. В статті зазначено стимулюючий вплив венчурного капіталу в інноваційному та економічному зростанні крайни, а також не одностайність умов та чинників впливу на процес венчурного інвестування. Це також потребує подальшого дослідження, бо лишається відкритим питання розриву наявного для окремих країн розриву між показниками
} 
економічного зростання, інновачійності та обсягів венчурного інвестування. Крім того, для майбутніх досліджень необхідним є визначити більш глибоко вплив ризику та асиметричності інформації на рух та обсяги венчурного капіталу.

Ключові слова: венчурний капітал, інновачійне зростання, економічне зростання, підприємництво, інноваційне підприємництво.

\author{
Виктория фон Розен, \\ кандидат экономических наук, дочент, \\ Институт выстего образования, \\ ГВУЗ «Киевский национальный экономический университет \\ имени Вадима Гетьмана»
}

\title{
ВЕНЧУРНЫЙ КАПИТАЛ И ЕГО ВЛИЯНИЕ НА ИННОВАЦИОННЫЙ И ЭКОНОМИЧЕСКИЙ РОСТ СТРАН
}

\begin{abstract}
В статье рассмотрена сущность экономического и инновационного развития, а также инновационного предпринимательства. Проведен анализ объемов венчурного инвестирования и показателей ВВП по отдельно выбраннылм странам. Отмечены основные взаимосвязи и факторы воздействия на процессы венчурного инвестирования, такие как риск и асимметричность информации. Исследована роль венчурного капитала в инновачионном и экономическом развитии стран, продемонстрировано практическое содержание отдельных приведенных теоретических положений. Также показан отрыв по вопросам венчурного инвестирования между отдельными странами.

Определены дальнейшие направления исследования построения модели возможньх вариантов инновационного развития на базе оживления венчурного инвестирования и развития инновационного предпринимательства для развивающихся стран. В статье отмечено стимулирующее влияние венчурного капитала в инновационном и экономическом росте страны, а также различие условий и факторов влияния на процесс венчурного инвестирования. Это также требует дальнейшего исследования, поскольку остается открытым вопрос о существовании для отдельных стран разрыва между показателями экономического роста, инновационности, а также объемов венчурного инвестирования. Кроме того, необходимо для будущчи исследований определить более глубокое влияние риска и асимметричности информации на движение и объемы венчурного капитала.

Ключевые слова: венчурный капитал, инновационный рост, экономический рост, предпринимательство, инновационное предпринимательство.
\end{abstract}

Introduction. The issue of economic development of countries and its incentives is relevant both for countries with developed economies and for developing countries. It is necessary in this process to ensure innovation movements and appropriate technological changes. In this context, the issue of investing in innovative areas is important. Venture capital can play a significant role in the development of entrepreneurship and innovation. Recent changes in the technological paradigm, the main trends of economic development demonstrate the latest opportunities for the vast majority of countries.

In this context it is relevant that economies create as much venture capital as possible because future possibilities and opportunities for wealth and progress depend on it. In this respect the US is leading in its success to do so.

Review of the latest research and literature. "The economy itself does not grow into higher forms. Its data do not mix like plastic clay. Neither data nor data-based cataclysmic logic decide the economic destiny of nations. A simple change in the data means little...." [1, p. 487] By quoting Joseph Schumpeter it becomes clear that a simple change in the data does not affect economic development and does not explain it. The following comparative table of Jochen Röpke and Olaf Stiller in the introduction of the 1st edition of Joseph A. Schumpeter's "Theorie der Wirtschaftlichen Entwicklung" ("Theory of Economic Development") (see Table 1) gives an idea of the main provisions of Schumpeter's theory of economic development and neoclassical economic theory, as well as their differences:

Table 1

The central differences between the mainstream economy and Schumpeter development $[1$, p.xxvii].

\begin{tabular}{|l|l|l|}
\hline \multicolumn{1}{|c|}{ Aspects } & \multicolumn{1}{c|}{ Neoclassical } & \multicolumn{1}{c|}{ Schumpeter } \\
\hline Source of regional growth & Increase in input (input logic) & Neocombination (innovation logic) \\
\hline Vehicle of growth & Routine, "Homo Oeconomicus", "Host" & "Entrepreneur" (innovator) \\
\hline $\begin{array}{l}\text { Function of science and } \\
\text { research }\end{array}$ & $\begin{array}{l}\text { Producer of new knowledge Application of } \\
\text { knowledge in the form of patents, licenses, } \\
\text { through transfer: "knowledge society" }\end{array}$ & $\begin{array}{l}\text { Without enforcement, knowledge remains } \\
\text { "dead": an entrepreneurial knowledge society }\end{array}$ \\
\hline Peter Drucker & "Doing things right" & "Do the right things" \\
\hline Allocation of the factors & $\begin{array}{l}\text { Optimal allocation of resources "whoever } \\
\text { optimizes wins" }\end{array}$ & $\begin{array}{l}\text { New combinations cannot be optimized. } \\
\text { "Who optimizes loses" }\end{array}$ \\
\hline motivation & Hedonism, profit, extrinsic & $\begin{array}{l}\text { Achievement motivation, enjoyment of } \\
\text { design, intrinsic }\end{array}$ \\
\hline
\end{tabular}


In fact, Schumpeter discovered the source of energy of modern society, namely-innovative entrepreneurship [1, p. xxvii].

In general, entrepreneurship plays an important, if not the decisive role in the creation and growth of business, as well as in the growth and prosperity of regions and countries [2, p. 5].

A special place in this sense is covered by the so-called venture capital business or business venture. This form of business makes it possible to start, develop and finance business activities in the most innovative (but also more risky) areas.

Accordingly, the economic value of venture capital is its ability to promote innovative development, growth and employment.

Venture capital business is directly related to such factors as risk, uncertainty, asymmetry and incomplete information [3-5]

In order to clarify these and some other provisions, we have considered the scientific work of such scientists as: J. Schumpeter; R. Hisrich, M. Peters, D. Shepherd; N. G. Mankiw, M.P.Taylor; D. Kahneman, as well as publications: Technology and innovation report 2021, UNCTAD; Treibstoff Venture Capital; Entrepreneurship at glance 2017, OECD 2017; OECD Business and Finance Outlook 2016; Global Innovation Index 2020 and so on.

Main purpose of the article is a study of the impact and importance of venture capital in the economic growth of countries with an emphasis on the innovative nature of such development.

\section{The objectives of the study are:}

- clarification of theoretical provisions on economic growth and innovative entrepreneurship, venture capital and venture capital business,

- determination of the main characteristic conditions of venture investment: risk and asymmetry of information,

- analysis of statistical information on the volume of venture capital by selected countries, GDP and GDP per capita by the same countries,

- summarizing the results of the study on the role of venture capital in the economic growth of countries and clarifying the innovativeness of such growth.

Statements of main issues of the study.

The main theoretical provisions considered by us are relevant to the following issues (see Fig. 1).

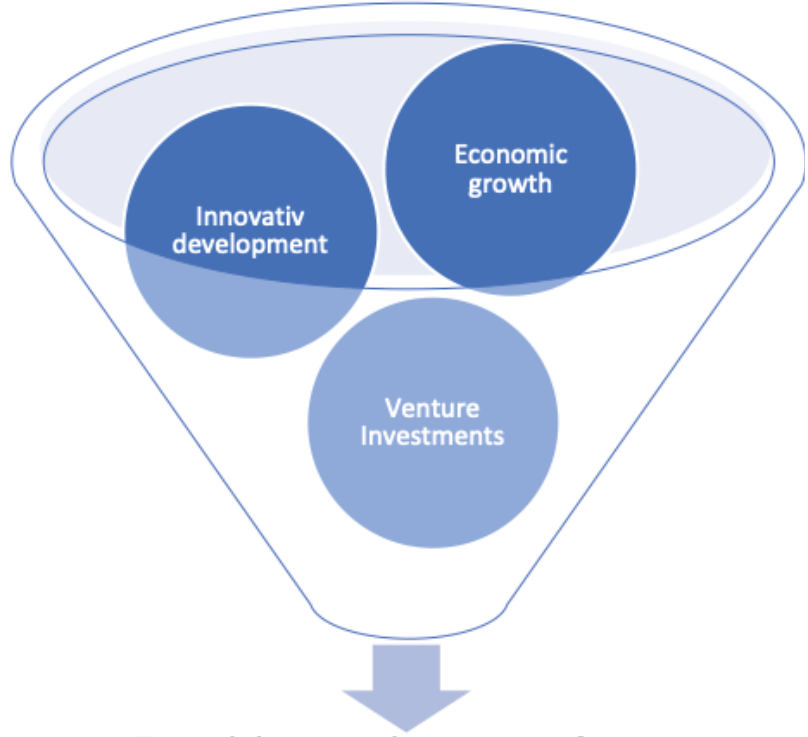

Essential venture investments factors:

Risks;

Asymmetric information

Fig. 1. Economic Development and Venture Investment [by author]

Periods of economic growth in most countries are different. Periods of economic growth are replaced by periods of slowdown and reduction [6, p. 455]. We can follow the dynamics of these changes according to the graphs below, which show the dynamics of GDP [6].

Noteworthy are the changes that have taken place in the last 40 years through the ICT (Information and communication technology) period to the so-called Industry 4.0. These changes are impressive. Now we can define 
the new conditions of industry 5.0, the change of technological paradigm. At the same time, the differentiation between countries and entire regions continues to grow [7].

Venture capital investments vary greatly in regional terms. In addition, companies that have been invested through venture capital are mostly young companies. Only a small number of companies used venture capital. For example, in 2016, less than 1\% of OECD companies were financed through new venture capital. In 2016, the average investment per company was $\$ 5$ million in Canada, Ireland, Israel and the United States, while the four largest countries in Europe in terms of economic development, France, Germany, Italy and Spain, are in positions between 1 and 2 million dollars. Between 2007 and 2008, the share of venture capital investment in companies with less than 20 employees increased from $30 \%$ to $40 \%$ in Europe [8, p.7; 9].

Consider the amount of venture investment in the United States and other countries, such as the United Kingdom, Japan, Germany, Switzerland and Canada. The cities of these countries occupy top positions among the world's leading financial centers. The analysis was performed according to OECD data, data for China were not taken into account (see Fig. 2):

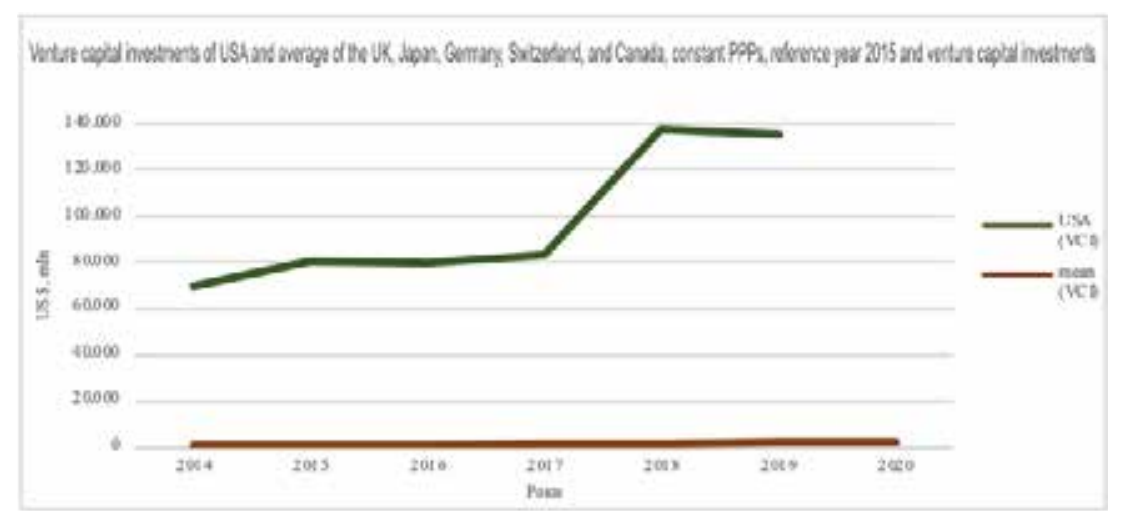

Fig. 2. Venture capital investment in the United States and the weighted average of countries such as the United Kingdom, Japan, Germany, Switzerland and Canada [compiled from open data OECD, 10, is also contained in the conference "Prospects for effective management decisions in business and projects", September 16-17, 2021, Odessa, Ukraine]

According to the figure, we can conclude that there is a significant excess of venture capital in the United States, although positive dynamics are present in other countries, as well.

The question remains why the US are leading in the creation of venture capital. One of the reasons is simply and with it the capital market. Others are a less developed social security systems which forces individuals to work for privately financed pension or retirement systems. This is due specifically compared to the countries in the present European Union. There we see an ongoing discussion how to shorten the gap to the development in the USA.

Comparing the dynamics of changes in venture capital with changes in GDP and GDP per capita, it is important to note the persistence of positive growth trends (except for the last period, 2020, and the impact of the CORONA pandemic). It can also be assumed that countries with more significant indicators that characterize the development of the economy show higher rates of venture investment (see Fig. 3). The situation with the GDP per capita is not so unanimous, but the general correspondence between the level of economic development and venture investment remains (see Fig. 4).

It is almost impossible to estimate the interdependence of the main indicators of the country's GDP, GDP per capita, and venture capital investments, but it is possible to assume that such a dependence exists. Further research in this direction is needed.

The large gap in venture capital between European countries and the United States is due to the influence of certain factors. There are also differences in the implementation of innovation development policies.

Taking into account the practice of the United States, it should be noted the significant impact of venture capital on the transformation of the innovation process. Venture capitalists provide financial assistance in the development of high-tech business. They authentically cultivate relationships and opportunities to become part of financial institutions, universities, large companies, business companies and other organizations [12]. This presence facilitates the perception and direction of information flows, as well as reduces the risks associated with the creation and / or subsequent operation of a new business. 


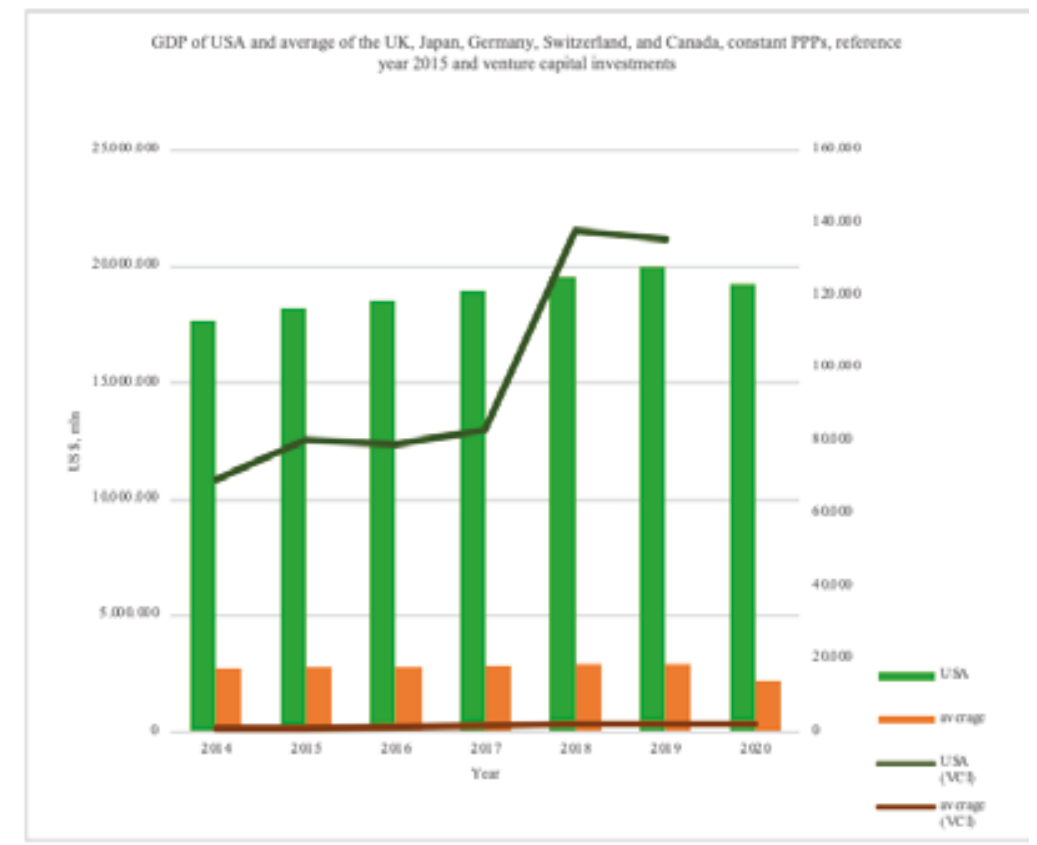

Fig. 3. GDP of USA and average of the UK, Japan, Germany, Switzerland, and Canada, constant PPPs, reference year 2015 and venture capital investments [compiled from open data OECD, 10, 11]

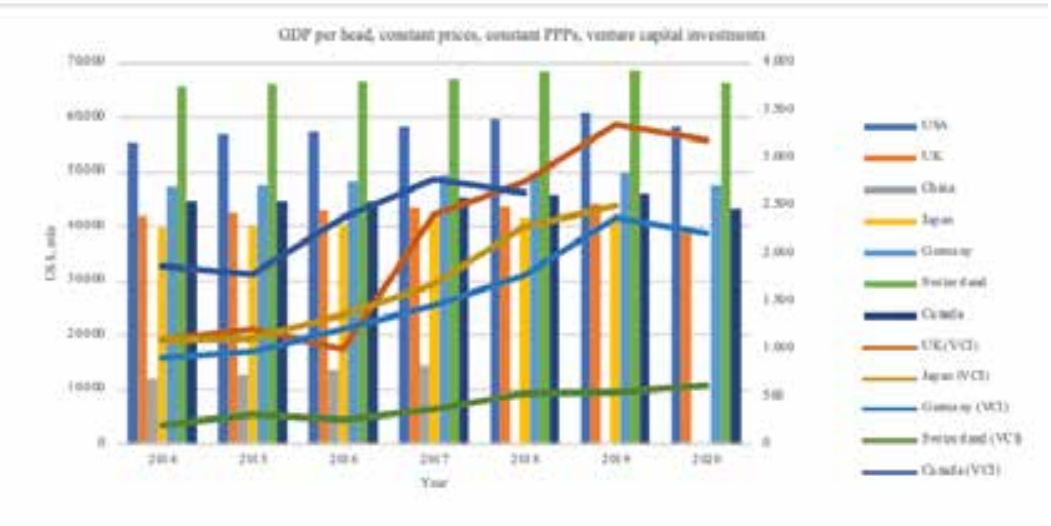

Fig. 4. GDP per head, constant prices, constant PPPs, venture capital investments [compiled from open data OECD, 10, 11]

If we talk more specifically about the current global trends in venture investment, innovation and economic development, it should be noted that in terms of patent registration, for example, Germany is the second country in the world after the United States. Berlin and Munich occupy leading positions on the startup scene in the world. German companies are moving forward and therefore a clear proof - the company Biotech with a vaccine developed by it. However, in terms of funding for high-tech companies, Germany is not in first place. Here the capital market, the level of its efficiency and infrastructure development, investor confidence have a significant impact [13].

For entrepreneurs - consumers of venture investment, it means, first of all, the opportunity to attract the necessary funding. [13] The advantage of the American capital market is the presence of investors willing to invest money, the existence of the so-called ecosystem, a clear legal framework, a clear tax base. In general, it can be noted that innovations, patent registration, investments play a significant role in the competition of enterprises in the economies of individual countries.

Quoting from GLOBAL INNOVATION INDEX 2020: "Who will Finance Innovation?" „The key answer to the question is: startups, venture capital, other sources of innovation funding “ [14, p. xix]. According to GII 2020, the most active centers of venture capital remain Singapore, Israel, China, Hong Kong (China), Luxemburg, the United States of America, India, United Kingdom. Under the influence of the pandemic conditions, certain changes have taken place in the areas of venture investment - that is health, online education, big data, e-commerce, robotics. 
In general, the issue of the impact of venture capital on economic growth [15], the role of venture capital in financing innovation [16] is given considerable attention by world scientific circles. Special attention is also paid to the need to stimulate the development of entrepreneurship $[17 ; 18]$.

Summing up the impact of venture capital on innovation and economic growth, it is worth noting the role of venture capital as a catalyst for technological change, as well as, on the one hand, a generator of costs and, on the other hand, a breakthrough generator of other types of innovation, conventional research centers [12].

\section{Conclusions.}

The relationship between such basic concepts as innovation and economic development, venture investment and innovative entrepreneurship was identified.

Speaking about the impact of venture capital on innovation and economic growth, it should be noted the stimulating nature of such impact in the presence of controversial issues of its role. This is due to the disagreement of the ability to determine the level of economic development of the country and other influencing factors that determine the capabilities and conditions of the country's capital market.

Further tasks in the study of this area are to build a model of possible options for innovative development based on the revival of venture capital and the development of innovative entrepreneurship for developing countries. Additionally it is not substanstially analysed, whether the present central bank policy has influenced investors decicions and when this might change.

\section{References:}

1. Schumpeter, J. (2006). Theorie der wirtschaftlichen Entwicklung. Nachdruck der 1. Auflage von 1912. Berlin: Duncker \& Humbolt, 487.

Schumpeter, J. (2006). Theorie der wirtschaftlichen Entwicklung [Robert D. Hisrich, Michael P. Peters, Dean A. (2020). Shepherd Entrepreneurship. McGraw-Hill Education, 5.

2. Robert D. Hisrich, Michael P. Peters, Dean A. (2020). Shepherd Entrepreneurship. McGraw-Hill Education, 5.

Robert D. Hisrich, Michael P. Peters, Dean A. (2020). Shepherd Entrepreneurship. McGraw-Hill Education. [in English]

3. Kahneman, D. (2012). Schnelles Denken, langsames Denken. Penguin Verlag.

4. Kahneman, D. (2012). Schnelles Denken, langsames Denken [Fast thinking, slow thinking]. Penguin Verlag. [in German]

5. Feld, B., Mendelson, J. (2019). Venture Deals. Be smarter than your lawyer and venture capitalist. Fourth Edition, Wiley.

Feld, B., Mendelson, J. (2019). Venture Deals. Be smarter than your lawyer and venture capitalist. Fourth Edition, Wiley. [in English]

6. Ramsinghani, M. (2021). The business of venture capital. The art of raising a fund, structuring investments, portfolio management, and exits. Wiley Finance Series.

Ramsinghani, M. (2021). The business of venture capital. The art of raising a fund, structuring investments, portfolio management, and exits. Wiley Finance Series. [in English]

7. Mankiw N. G., Taylor M. P. (2017). Economics. Cengage Learning EMEA, 455.

8. Mankiw N. G., Taylor M. P. (2017). Economics. Cengage Learning EMEA. [in English]

9. Technology and innovation report 2021. (UNCTAD). https://unctad.org/system/files/official-document/tir2020 en.pdf (22 august 2021)

Technology and innovation report 2021. (UNCTAD). https://unctad.org/system/files/official-document/tir2020 en.pdf [in English] (22 august 2021)

10. Treibstoff Venture Capital: Wie wir Innovation und Wachstum befeuern (Bundesverband Deutscher Kapital beteiligungsgesellschaften e.V., Internet Economy Faundation, Roland Berger GmbH) https://www.yumpu.com/de/ document/view/61778382/treibstoff-venture-capital-wie-wir-innovation-und-wachstum-befeuern, 7 (22 august 2021)

Treibstoff Venture Capital: Wie wir Innovation und Wachstum befeuern (Bundesverband Deutscher Kapitalbet eiligungsgesellschaften e.V., Internet Economy Faundation, Roland Berger GmbH) [Fuel Venture Capital: How we fuel innovation and growth (Bundesverband Deutscher Kapitalbeteiligungsverbindungen e.V., Internet Economy Faundation, Roland Berger GmbH)] https://www.yumpu.com/de/document/view/61778382/treibstoff-venture-capitalwie-wir-innovation-und-wachstum-befeuern [in German] (22 august 2021)

11. 9 Entrepreneurship at a Glance 2017. (OECDiLibrary). https://www.oecd-ilibrary.org/docserver/entrepreneur aag-2017-en.pdf?expires $=1623137685 \&$ id $=$ id\&accname $=$ guest\&checksum=7D2C9C9DB6AE5DB81AB96A0E5CD 58B54 (22 august 2021)

12. Entrepreneurship at a Glance 2017. (OECDiLibrary). https://www.oecd-ilibrary.org/docserver/entrepreneur aag-2017-en.pdf?expires $=1623137685 \&$ id $=$ id\&accname $=$ guest\&checksum=7D2C9C9DB6AE5DB81AB96A0E5CD 58B54 [in English] (22 august 2021)

13. 10 Venture capital investments. (OECD) https://stats.oecd.org/Index.aspx?DataSetCode=VC_INVEST ()

14. Venture capital investments. (OECD) https://stats.oecd.org/Index.aspx?DataSetCode=VC_INVEST [in English] (22 august 2021)

15. Gross domestic product. (OECD) https://stats.oecd.org/index.aspx?queryid=60705 (22 august 2021) 
Gross domestic product. (OECD) https://stats.oecd.org/index.aspx?queryid=60705 [in English] (22 august 2021)

16. Richard L. Florida, Martin Kenney Venture capital-financed innovation and technological change in the USA https://www.sciencedirect.com/science/article/abs/pii/0048733388900388 (22 august 2021)

Richard L. Florida, Martin Kenney Venture capital-financed innovation and technological change in the USA https:// www.sciencedirect.com/science/article/abs/pii/0048733388900388 [in English] (22 august 2021)

17. Auslandslistings von BioNTech, CureVac \& Co. Handlungsempfehlungen an die Politik für mehr Börsengänge in Deutschland. (2021) (Studien des Deutschen Aktieninstituts, Deutsches Aktieninstitut e.V. und RITTERSHAUS Rechtsanwälte Partnerschaftsgesellschaft mbB).

Auslandslistings von BioNTech, CureVac \& Co. Handlungsempfehlungen an die Politik für mehr Börsengänge in Deutschland. (2021) (Studien des Deutschen Aktieninstituts, Deutsches Aktieninstitut e.V. und RITTERSHAUS Rechtsanwälte Partnerschaftsgesellschaft mbB) [Foreign listings from BioNTech, CureVac \& Co. Recommendations for action to politicians for more IPOs in Germany. (2021) (Studies by the Deutsches Aktieninstitut, Deutsches Aktieninstitut e.V. and RITTERSHAUS Rechtsanwälte Partnerschaftsgesellschaft mbB)] [in German].

18. GLOBAL INNOVATION INDEX 2020. Who will finance innovation? 13th edition, Ithaca, Fontainebleau, and Geneva: Cornell University, INSEAD, and WIPO. https:/www.wipo.int/edocs/pubdocs/en/wipo_pub_gii_2020.pdf, xix (22 august 2021)

GLOBAL INNOVATION INDEX 2020. Who will finance innovation? 13th edition, Ithaca, Fontainebleau, and Geneva: Cornell University, INSEAD, and WIPO. https://www.wipo.int/edocs/pubdocs/en/wipo_pub_gii_2020.pdf [in English] (22 august 2021)

19. Akcigit U., Dinlersoz E., Greenwood J., Penciakova V. Synergising ventures: The impact of venture capitalbacked firms on the aggregate economy. (VOX EU, CEPR). https://voxeu.org/article/impact-venture-capital-backedfirms-aggregate-economy (22 august 2021)

Akcigit U., Dinlersoz E., Greenwood J., Penciakova V. Synergising ventures: The impact of venture capital-backed firms on the aggregate economy. (VOX EU, CEPR). https://voxeu.org/article/impact-venture-capital-backed-firmsaggregate-economy [in English] (22 august 2021)

20. Nanda J. L. R. Venture Capital's Role in Financing Innovation: What We Know and How Much We Still Need to Learn. Harvard Business School: Working Paper 20-131. https://www.hbs.edu/ris/Publication\%20Files/20-131_ fc73af76-3719-4b5f-abfc-1084df90747d.pdf (22 august 2021)

Nanda J. L. R. Venture Capital's Role in Financing Innovation: What We Know and How Much We Still Need to Learn. Harvard Business School: Working Paper 20-131. https://www.hbs.edu/ris/Publication\%20Files/20-131_ fc73af76-3719-4b5f-abfc-1084df90747d.pdf [in English] (22 august 2021)

21. Financing start-ups and grows: Overview of funding instruments. (Bundesministerium für Wirtschaft und Energie) https://www.bmwi.de/Redaktion/EN/Dossier/financing-for-start-ups-company-growth-and-innovations.html (22 august 2021)

Financing start-ups and grows: Overview of funding instruments. (Bundesministerium für Wirtschaft und Energie) https://www.bmwi.de/Redaktion/EN/Dossier/financing-for-start-ups-company-growth-and-innovations.html [in English] (22 august 2021)

22. Pandey I. M., Awasthi D. Entrepreneurship and Venture Capital. (ResearchGate). https://www. researchgate.net/profile/I-M-Pandey/publication/307898164_Entrepreneurship_and_Venture_Capital/

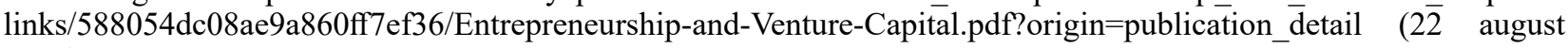
2021)

Pandey I. M.,Awasthi D. Entrepreneurship and Venture Capital.(ResearchGate). https://www.researchgate.net/profile/ I-M-Pandey/publication/307898164_Entrepreneurship_and_Venture_Capital/links/588054dc08ae9a860ff7ef36/ Entrepreneurship-and-Venture-Capital.pdf?origin=publication_detail [in English] (22 august 2021) 